\title{
Croton calcareus: a new species of dragon's blood (Euphorbiaceae) from dry forest in the state of Chiapas, Mexico
}

\author{
Leticia MATEO-RAMÍREZ ${ }^{1} \&$ Ricarda RIINA ${ }^{2, *}$ \\ ${ }^{1}$ Department of Botany, Faculty of Biology, University of Salamanca, Licenciado Méndez Nieto Ave., \\ 37007, Salamanca, Spain. \\ ${ }^{2}$ Real Jardín Botánico, RJB-CSIC, Plaza de Murillo 2, 28014, Madrid, Spain. \\ *Corresponding author: rriina@rjb.csic.es \\ ${ }^{1}$ Email: leticiamr13@usal.es
}

\begin{abstract}
We describe Croton calcareus Riina \& Mateo-Ram. sp. nov., a new species in Croton section Cyclostigma (dragon's blood trees) from the state of Chiapas (Mexico). This species is a small tree growing in dry forest on calcareous substrates. Both morphological and molecular data support C. calcareus sp. nov. as a new species closely related to C. redolens, another dry forest taxon from northern Venezuela. We provide illustrations, a distribution map and suggestions for species conservation status. The new species along with Croton draco are the only known representatives of $C$. section Cyclostigma occurring in Mexico.
\end{abstract}

Keywords. Croton section Cyclostigma, dry forest, Euphorbiaceae, Neotropics, phylogeny.

Mateo-Ramírez L. \& Riina R. 2020. Croton calcareus: a new species of dragon's blood (Euphorbiaceae) from dry forest in the state ofChiapas, Mexico. European Journal of Taxonomy 657: 1-14.https://doi.org/10.5852/ejt.2020.657

\section{Introduction}

Croton L. species popularly known as dragon's blood ('sangre de drago' or 'sangre de grado' in Spanish) belong to $C$. sect. Cyclostigma Griseb. This section is an arborescent clade of 48 species occurring mainly in lowland and montane forests along the Andes (Riina et al. 2009; van Ee et al. 2011) and the Atlantic Rain Forest region in south-eastern Brazil (Santos et al. 2017; Farias et al. 2019). In the northern Neotropics, only one species in the section, Croton draco Schltdl., was previously known to reach Mexico.

As part of a revision of the common and widespread Croton draco, which occurs from Mexico to Panama, we noticed several specimens from Mexico that had obvious morphological differences with $C$. draco as well as differences in habitat. Further examination of these specimens revealed an undescribed taxon, which we assign here to $C$. sect. Cyclostigma based on its morphological affinities with species in this section and support from molecular phylogenetic evidence.

Members of sect. Cyclostigma have laticifers that produce conspicuous reddish latex (Wiedenhoeft et al. 2009; Feio et al. 2018a) that is widely used for its medicinal properties in several Latin American 
countries (Jones 2003; Salatino et al. 2007). Species from sect. Cyclostigma occur predominantly in mesic forests (Riina et al. 2009; Arévalo et al. 2017); however, a small number of species are restricted to seasonally dry forest vegetation in different areas of the Neotropics, such as C. churutensis Riina \& Cornejo (Riina et al. 2007) in Ecuador, C. tumbesinus Riina (Feio et al. 2018b) in Peru, C. redolens Pittier in northern Venezuela and C. charaguensis Standl. in Bolivia. In this paper, we describe and illustrate a new species from the state of Chiapas (Mexico), which adds to the list of dry forest specialists of this diverse and medicinally important Neotropical Croton clade.

\section{Material and methods}

We examined collections of the new taxon and $C$. draco deposited in BM, DAV, MA, MEXU, MICH and MO. Acronyms of herbaria follow Index Herbariorum (Thiers, continuously updated). For morphological descriptions we used a 10-60 × magnification stereo microscope. Morphological terminology follows recent taxonomic papers on Croton (e.g., Santos et al. 2017; Feio et al. 2018b; Riina et al. 2018), and anatomical studies on trichomes and secretory structures (Webster et al. 1996; Vitarelli et al. 2015; Feio et al. 2016; Feio et al. 2018a).

For the phylogenetic analysis, we used a subset of the nuclear rDNA internal transcribed spacers (ITS) dataset from Riina et al. (2009), including species of sect. Cyclostigma sampled there, a selection of other Croton sections and one outgroup (Brasiliocroton mamoninha P.E.Berry \& Cordeiro). To this dataset, we added two newly generated sequences of the new species, $C$. calcareus Riina \& MateoRam. sp. nov., and two sequences of $C$. draco from GenBank (https://www.ncbi.nlm.nih.gov/genbank/). GenBank accession numbers of all the sequences used in the analysis are shown in Table 1. DNA extraction, amplification and sequencing of ITS followed the same laboratory procedures as in previous Croton phylogenetic studies (Riina et al. 2009; van Ee et al. 2011). Sequences were aligned manually using Mesquite ver. 3.2 (Maddison \& Maddison 2017). The aligned matrix, in fasta format, is provided as Supplementary file 1.

The phylogenetic analysis was performed in MrBayes 3.2.6 (Ronquist et al. 2012) using the GTR $+\mathrm{I}+\mathrm{G}$ substitution model as estimated with jModelTest 2.1.6 (Darriba et al. 2012) using the Akaike Information Criterion (AIC). The analysis included two runs of 10 million generations in MrBayes, sampling trees every 1000 generations. One-fourth (25\%) of the MCMC samples from each run was discarded as 'burnin'. Tracer ver. 1.7.1 (Rambaut et al. 2014) was used to determine run convergence and stationarity as indicated by the effective sample size (ESS) values, which should be higher than 200. Node posterior probability (PP) values were obtained by computing a 50\% majority rule consensus of the post-burn-in trees from both MCMC chains using the sumt command. We used FigTree ver. 1.3.1 (Rambaut 2006) to visualize and edit the consensus tree.

We ran a preliminary analysis with all the Cyclostigma accessions from Riina et al. (2009) to assess the phylogenetic position of C. calcareus sp. nov. within the section (data not shown). Based on this preliminary phylogeny, we reduced the sampling within the Cyclostigma clade to exclude taxa distantly related from C. calcareus sp. nov. (i.e., all the Brazilian species from the Atlantic Rain forest and most species from the south-central Andes). We ran the final Bayesian analysis on the reduced dataset (Table 1) following the steps indicated above.

The species distribution map was produced using R software (https://www.r-project.org) and the dismo package (Hijmans et al. 2010). Only two of the seven available collections had geographic coordinates on their labels, so we estimated coordinates for the remainder with the locality information using Google Earth. The proposed conservation status was based on the criteria of the International Union for the Conservation of Nature Guidelines (IUCN 2012). Extent of occurrence (EOO) was assessed using GeoCat (Bachman et al. 2011). 
Table 1. List of GenBank accession numbers of the ITS sequences used to provide a phylogenetic context to the new species (shown in Fig. 1).

\begin{tabular}{|c|c|}
\hline Brasiliocroton mamoninha P.E.Berry \& Cordeiro & EU586944 \\
\hline Croton arboreus Millsp. & EU478029 \\
\hline C. beetlei Croizat & EU586916 \\
\hline C. calcareus Riina \& Mateo-Ram. sp. nov.; Hampshire et al. 1161; Mexico: Chiapas & MT106663 \\
\hline C. calcareus Riina \& Mateo-Ram. sp. nov.; Webster et al. 12966; Mexico: Chiapas & MT106664 \\
\hline C. caracasanus Pittier & DQ227525 \\
\hline C. chilensis Müll.Arg. & EU586905 \\
\hline C. conduplicatus Kunth & EU477957 \\
\hline C. coriaceus Kunth & EU586921 \\
\hline C. cuneatus Klotzsch & EU497735 \\
\hline C. cupreatus Croizat & EU586919 \\
\hline C. curiosus Croizat & EU586906 \\
\hline C. discolor Willd. & EU497736 \\
\hline C. draco Schltdl. \& Cham. 1 & EU478006 \\
\hline C. draco 2 & EF421776 \\
\hline C. echioides Baill. & EU586907 \\
\hline C. eichleri Müll.Arg. & EU586949 \\
\hline C. emporiorum Croizat & EU586908 \\
\hline C. gossypiifolius Vahl & EU586924 \\
\hline C. goudotii Baill. & EU586946 \\
\hline C. gratissimus Burch. (as C. zambesicus in GenBank) & AY971260 \\
\hline C. hibiscifolius Kunth ex Spreng. & EU586925 \\
\hline C. lundellii Standl. & EF421735 \\
\hline C. niveus Jacq. & EU478046 \\
\hline C. pachypodus G.L.Webster (as C. megistocarpus in GenBank) & EU586953 \\
\hline C. priscus Croizat & EU586950 \\
\hline C. pungens Jacq. & AY971241 \\
\hline C. redolens Pittier & EU586935 \\
\hline C. rimbachii Croizat & EU586936 \\
\hline C. saltensis Griseb. & EU586911 \\
\hline C. sampatik Müll.Arg. & EF421792 \\
\hline C. sapiifolius Müll.Arg. & EF421754 \\
\hline C. schiedeanus Schltdl. & AY971246 \\
\hline C. speciosus Müll.Arg. & AY971251 \\
\hline C. suberosus Kunth & EU477979 \\
\hline C. verapazensis Donn.Sm. & EF421750 \\
\hline C. xalapensis Kunth & EU477987 \\
\hline C. yavitensis Croizat & EU586918 \\
\hline
\end{tabular}




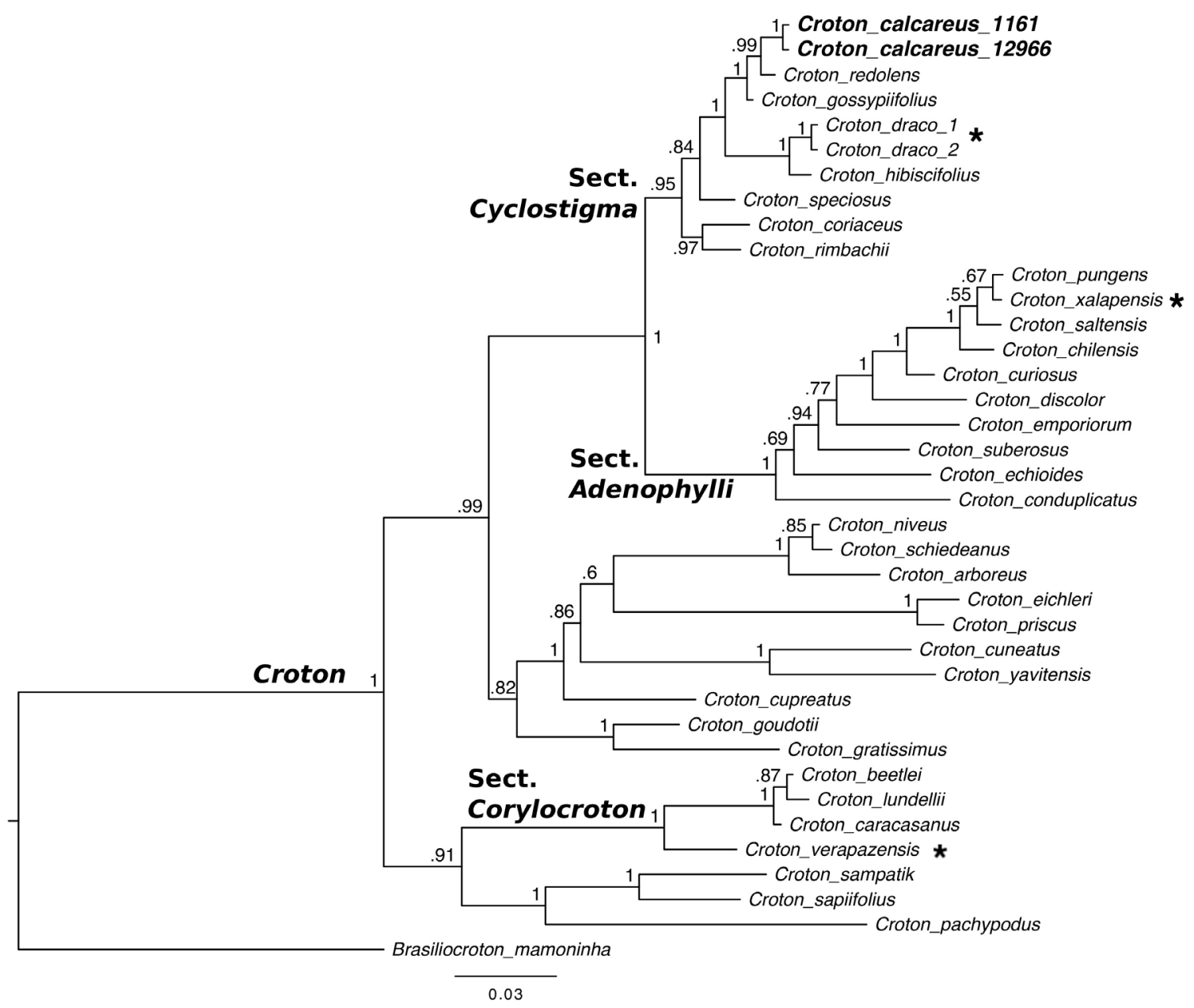

Fig. 1. Bayesian majority rule consensus phylogram of nuclear ITS data from a selection of Croton L. taxa including two accessions of Croton calcareus Riina \& Mateo-Ram. sp. nov. Species marked with an asterisk correspond to those with which $C$. calcareus sp. nov. has been previously confused. The relevant clades are labelled on the left side. Numbers next to nodes indicate clade support (Bayesian posterior probabilities).

\section{Results}

Class Magnoliopsida Brongn.

Order Malpighiales Mart.

Family Euphorbiaceae Juss.

Genus Croton L.

Croton calcareus Riina \& Mateo-Ram. sp. nov. urn:lsid:ipni.org:names:77209678-1

Figs $2-4$

\section{Diagnosis}

Croton calcareus Riina \& Mateo-Ram. sp. nov. is most closely related to C. redolens Pittier and can be distinguished from the latter mainly by its larger fruits $(12-13 \times 12-15 \mathrm{~mm}$ in C. calcareus sp. nov. vs 5-6 $\times 7-8 \mathrm{~mm}$ in C. redolens) and an indumentum of sessile, stellate, multiradiate, porrect trichomes on the adaxial side of leaves (vs stipitate, stellate, porrect trichomes in C. redolens). The new species 
has been confused with $C$. draco Schltdl., another dragon's blood from Mexico, but it differs from this species in having shorter inflorescences $(8-10 \mathrm{~cm}$ vs $15-43 \mathrm{~cm}$ in C. draco) and larger fruits (only 4-7 $\times$ 4-7 $\mathrm{mm}$ in C. draco).

\section{Etymology}

The specific epithet refers to the calcareous substrates where the species occurs.

\section{Type material}

MEXICO - Chiapas, Mpio, La Trinitaria, $4 \mathrm{~km}$ E of La Trinitaria along Mex 190; $16^{\circ} 8^{\prime} \mathrm{N}, 92^{\circ} 2^{\prime} \mathrm{W}$; alt. 1480 m; 8 Jul. 1990; R.J. Hampshire, A. Reyes García and L. Hernández 1161; holotype: MEXU[858873]; isotypes: BM, MA[540108], MO[4323513].

\section{Paratypes}

MEXICO - Chiapas - Mpio, Ocozocoautla, steep-walled canyon at the head of the Río de la Venta at the Chorreadero near Derna; 16 Dec. 1972; D.E. Breedlove, R.F. Thorne 30301; MEXU • El Aguacero, $13 \mathrm{~km}$ al NO de Ocozocoautla; 29 Mar. 1985; E. Cabrera and H. de Cabrera 7870; MEXU • E1 Aguacero, canyon of the Río La Venta; alt. 540-660 m; 19 Nov. 1984; G. Davidse, M. Sousa, O. Tellez, E. Martinez and J. Davidse 30083; MA, MO $13 \mathrm{~km}$ E of Ocozocoautla on Rte 190, then N on road to Aguacero; alt. 630-700 m; 2 Oct. 1984; M.J. Huft, E. Cabrera and R. Torres 2253; MEXU, MO • "Cascada El Aguacero en el Río La Venta" [El Aguacero waterfall on the river La Venta]; $16^{\circ} 45^{\prime} 17^{\prime}$ N, 93³1'20" W; alt. 600 m; 12 Dec. 1987; E. Martinez and A. Reyes 22018; MEXU, MICH • El Aguacero, "a 33 km al E de Cintalapa" [33 km E of Cintalapa]; alt. 540-660 m; 19 Nov. 1984; O. Tellez, M. Sousa, E. Martinez, G. Davidse and J. Davidse 8120; MO, MEXU • 7 mi SW of Tuxtla Gutierrez; alt. 3000 ft.; 11 Aug. 1962; G.L. Webster, K. Miller and L. Miller 12966; DAV, MO.

\section{Description}

Small monoecious trees, up to $6 \mathrm{~m}$ high; young branches with a dense indumentum of rosulate (sometimes also stipitate) trichomes; latex from the main trunk and branches reddish to dark red (observation from herbarium specimens). Stipules short-triangular when young $(\mathrm{ca} 1.5 \mathrm{~mm})$ to filiform 8-13.5 mm long, covered with a dense indumentum of rosulate and multiradiate trichomes, colleters (ovoid glands) at base, margin and apex. Leaf blade ovate to broadly ovate, $5-13 \times 3.5-11 \mathrm{~cm}$; base rounded to cordate; apex acute to obtuse; margin entire or slightly dentate; colleters (ovoid glands) along the margin; venation 3-5-plinerved, brochidodromous; primary and secondary veins raised on both surfaces; petiolar nectary glands 2-6, patelliform, sessile, subsessile or stipitate, attached to the petiole on the adaxial side, but also sometimes visible from the abaxial side; petiole $1.5-8 \mathrm{~cm}$ long, with a more or less dense indumentum of stellate adpressed trichomes; adaxial leaf indumentum very dense on young leaves to nearly glabrous on old leaves, sessile, stellate-porrect and stellate-multiradiate trichomes; abaxial leaf surface very densely pubescent on young leaves to sparser with age, with sessile or stipitate stellate or multiradiate trichomes. Inflorescences terminal, erect thyrses 8-10 cm long, axis costate, with a dense indumentum of stellatemultiradiate trichomes; bracts triangular, ca $1 \times 1 \mathrm{~mm}$; cymules usually bisexual, regularly spaced at the base and more congested toward the apex. Staminate flowers shortly pedicellate, pedicels $1-2 \mathrm{~mm}$ long; sepals valvate, triangular-ovate, $2-2.8 \times 1.1-2 \mathrm{~mm}$, adaxial surface with scattered simple trichomes, abaxial surface with a dense indumentum of stellate-multiradiate trichomes; petals narrow-elliptical, $1.7-1.8 \times 0.7-0.8 \mathrm{~mm}$, with scattered simple or stellate hairs on both surfaces, margin lanate; receptacle densely pilose; stamens 16; filaments glabrous, $2-3 \mathrm{~mm}$ long, anthers $0.6-0.9 \times 0.4-0.5 \mathrm{~mm}$. Pistillate flowers with pedicels $1.5-2 \mathrm{~mm}$ long, with stellate-multiradiate trichomes; sepals valvate, triangularovate, $2-2.2 \times 1.2-1.3 \mathrm{~mm}$, adaxial and abaxial surfaces with dense covering of stellate-multiradiate trichomes; petals absent or reduced to a filament with a colleter at the tip; ovary subglobose, densely covered with stellate-multiradiate trichomes; styles bifid, with six terminal tips, the lower half of the 


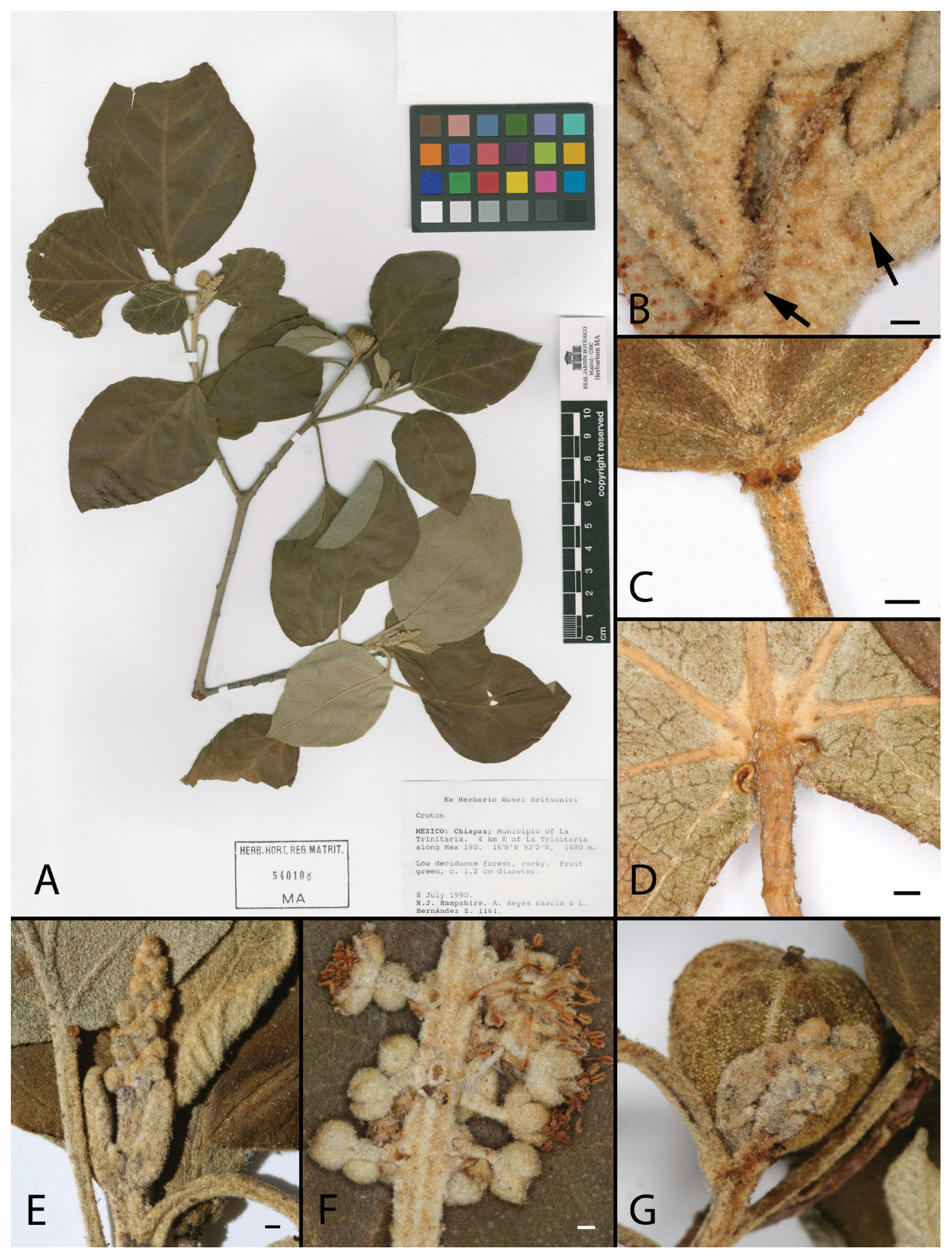

Fig. 2. Croton calcareus Riina \& Mateo-Ram. sp. nov. A. Image of an isotype (MA). B. Apical portion of a young branch showing the short young stipule (right arrow) and fully developed stipule (left arrow); the arrows point to the base of each stipule. C. Petiolar nectary glands visible from the adaxial side on a leaf with a rounded base. D. Petiolar nectary glands visible from the abaxial side on a leaf with a cordate base. E. Branch showing a young inflorescence. F. Section of inflorescence with detail of male flowers. G. Mature fruit. Scale bars $=1$ mm. Vouchers: A, C, E, G: Hampshire et al. 1161 (MA); B, D, F: Davidse et al. 30083 (MA). 


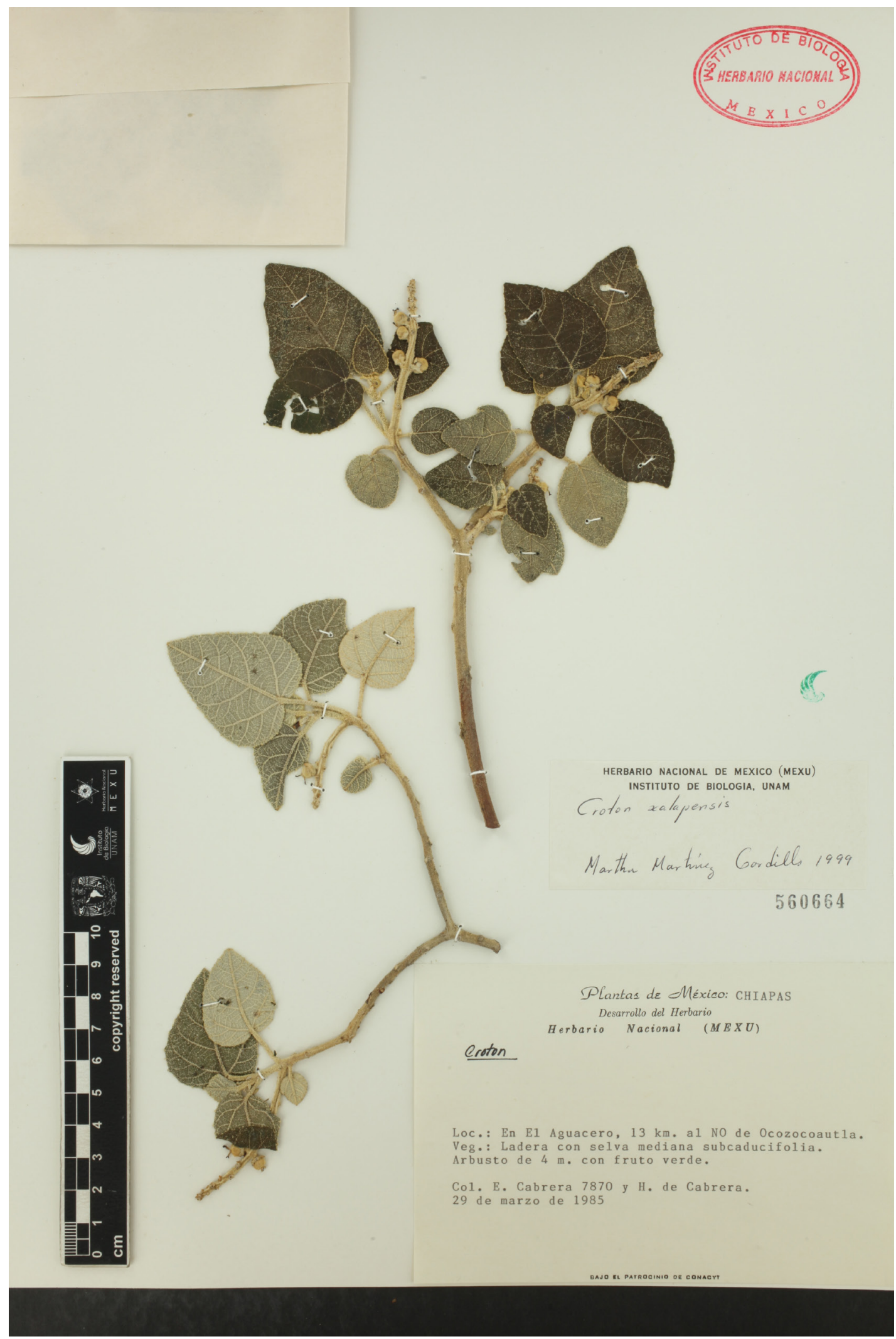

Fig. 3. Image of one of the paratypes of Croton calcareus Riina \& Mateo-Ram. sp. nov. (Cabrera and Cabrera 7870, MEXU), previously indentified as C. xalapensis Kunth, to show the variation in leaf shape and indumentum density. It also shows immature fruits (younger than those in the type specimens). 
styles with stellate-multiradiate trichomes. Capsules depressed-subglobose, slightly trilobate, $12-13 \times$ 12-15 mm; columella 9-10 mm long; seeds ovoid, 7-8 $\times 5.5-6 \mathrm{~mm}$, brown, surface smooth, shiny, caruncle trapezoid, $0.6 \times 1.2 \mathrm{~mm}$.

\section{Phylogenetic placement and relationships}

The ITS alignment consisted of 686 aligned positions. The resulting tree topology (Fig. 1) was congruent with previous analyses of Croton using the ITS region for the clades involved (Riina et al. 2009; van Ee et al. 2011). This phylogeny indicates that Croton calcareus sp. nov. is indeed a member of Croton sect. Cyclostigma and that it is most closely related to C. redolens and C. gossypiifolius Vahl (Fig. 1). The two sequences of $C$. calcareus sp. nov. are identical and share two unique positions with respect to the rest of sequences in the matrix. The accessions of Mexican species with which $C$. calcareus sp. nov. has been confused in the past (i.e., C. draco, C. xalapensis Kunth and C. verapazensis Donn.Sm.) are indicated with an asterisk in the phylogeny (Fig. 1). Of these, $C$. draco is the most closely related to the new species, coming out in the same clade (sect. Cyclostigma), the other two species belong to two different sections/clades of Croton (Fig. 1).

\section{Distribution, ecology and phenology}

Croton calcareus sp. nov. appears to be restricted to the state of Chiapas (Mexico) where it grows on limestone outcrops, in low deciduous forests on rocky slopes, steep river canyons and river floodplains,

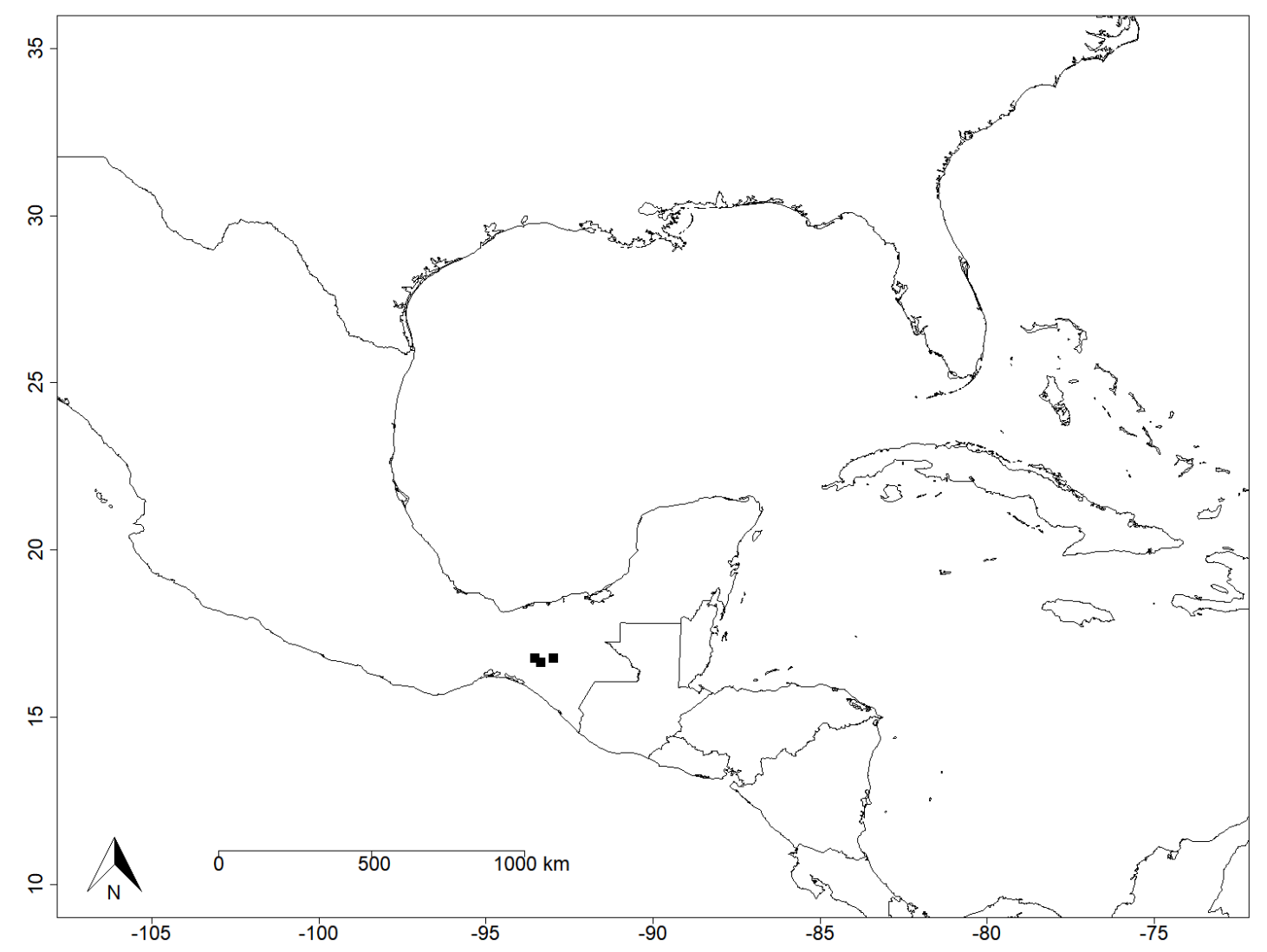

Fig. 4. Distribution map showing the localities (black squares) of Croton calcareus Riina \& MateoRam. sp. nov., all known from southern Mexico. 
between 550-1500 m elevation (Fig. 4). Flowering between August and February and probably fruiting between March and July.

\section{Conservation status}

The species could be categorized as Vulnerable (VU D2; IUCN 2012). The extent of occurrence of Croton calcareus sp. nov. is only $2718 \mathrm{~km}^{2}$ and it is only known from four different localities in two notadjacent municipalities. The species appears to be under low human pressure since three of the known localities (Municipality of Ocozocoautla) are within the buffer zone of the Selva el Ocote Biosphere Reserve (Ochoa-Gaona 1996; UNESCO 2012). Most of the known localities are of limited access due to their vicinity to limestone rocky formations along rivers.

\section{Discussion}

Our phylogenetic analysis supports Croton calcareus sp. nov. as a distinct lineage in $C$. sect. Cyclostigma sensu van Ee et al. (2011), which, combined with the observed distinct morphological features, warrants recognition at the species level. Based on the ITS phylogeny and morphology, the new species is most closely related to $C$. redolens, a dendroid shrub (up to $3 \mathrm{~m}$ tall) occurring in dry forest vegetation associated with rocky outcrops in northern Venezuela. Croton calcareus sp. nov. also belongs to the same clade that includes $C$. draco, the only other species in sect. Cyclostigma known to occur in Mexico. Characters shared among C. calcareus sp. nov., C. draco, C. redolens and other members of sect. Cyclostigma include, but are not limited to, arborescent habit, indumentum of stellate trichomes, red latex, conspicuous stipules, petiolar nectary glands, bisexual cymules at the lower portion of the inflorescence axis, bifid styles and more than 15 stamens. For this reason, it is not surprising that specimens of $C$. calcareus sp. nov. have been confused with $C$. draco in the past.

Among the many morphological differences between $C$. calcareus sp. nov. and both $C$. redolens and C. draco (Table 2), the most obvious ones are fruit size and inflorescence length; although the latter is only relevant in the case of $C$. draco. Inflorescences are much longer in $C$. draco and fruits are much larger in C. calcareus sp. nov. (Table 2). Unfortunately, only one of the examined collections (Hampshire et al. 1161, the type) had fully mature fruits and seeds. Plant stature and habitat preference are also important features setting the two Mexican species ( $C$. draco and C. calcareus sp. nov.) apart (Table 2).

There are also differences, although with some overlap, in the leaves among the three species in question. In Croton calcareus sp. nov. leaves can have a rounded or cordate base (Fig. 1C-D) and acute to obtuse apex, whereas in C. redolens the base is mostly rounded and rarely cordate and the apex is acute, and in C. draco the base of the leaves is usually cordate and the apex acuminate (Table 2). In addition, the texture of the adaxial leaf surface is soft to touch in C. draco and C. redolens, while in C. calcareus sp. nov. it has a rough texture. Stipules are usually informative distinguishing species within sect. Cyclostigma (Riina et al. 2009; Farias et al. 2019). In Croton calcareus sp. nov., there is variation in the shape of stipules depending on their state of development. When young, stipules in C. calcareus sp. nov. are triangular in shape and they become more linear and much longer as they grow (Fig. 1B), whereas in C. redolens and C. draco young and old stipules have more or less the same shape (Table 2).

Croton calcareus sp. nov. occurs in a diverse and relatively poorly explored area of Mexico in which species from different plant groups continue to be described (e.g., Martínez-Meléndez et al. 2014; Hirai et al. 2014; Ruiz-Sánchez 2015; Ortiz-Díaz et al. 2016; Steinmann \& Carrillo-Reyes 2018; Areces-Berazain \& Vega-Lopez 2019). Several specimens of C. calcareus sp. nov. have previously been misidentified in herbaria as $C$. draco, C. xalapensis or C. verapazensis. Besides $C$. draco, which belongs to the same section as the new species, the other two species belong to different sections or clades (Fig. 1). Croton xalapensis is a shrub in C. sect. Adenophylli Griseb., the largest section of 
Table 2. Main differences between Croton calcareus Riina \& Mateo-Ram. sp. nov., C. redolens Pittier and C. draco L. (the only other species in C. sect. Cyclostigma Griseb. occurring in Mexico).

\begin{tabular}{|c|c|c|c|}
\hline Feature & $\begin{array}{l}\text { Croton calcareus } \\
\text { sp. nov. }\end{array}$ & Croton draco & Croton redolens \\
\hline Stipules & $\begin{array}{l}\text { Short triangular to } \\
\text { long filiform }\end{array}$ & $\begin{array}{l}\text { Subulate to broadly } \\
\text { subulate }\end{array}$ & Short filiform \\
\hline Leaf size (max. cm) & $5-13 \times 3.5-11$ & $9.9-22.9 \times 6.6-17.7$ & $7.8-8.3 \times 4.8-6.3$ \\
\hline Leaf base & Rounded or cordate & $\begin{array}{l}\text { Cordate, rarely } \\
\text { rounded }\end{array}$ & $\begin{array}{l}\text { Rounded, rarely } \\
\text { cordate }\end{array}$ \\
\hline Leaf apex & Acute to obtuse & Acuminate & Acute \\
\hline Adaxial leaf texture & Rough & Soft & Soft \\
\hline Adaxial leaf trichomes & $\begin{array}{l}\text { Sessile, stellate } \\
\text { porrect and stellate } \\
\text { multiradiate }\end{array}$ & $\begin{array}{l}\text { Stipitate, stellate } \\
\text { multiradiate }\end{array}$ & $\begin{array}{l}\text { Stipitate, stellate } \\
\text { porrect }\end{array}$ \\
\hline Adaxial leaf indument & Sparse to glabrescent & Dense to very dense & Dense \\
\hline Inflorescence length $(\mathrm{cm})$ & $8-10$ & $14.6-42.5$ & $5.7-15.6$ \\
\hline Fruit size (mm) & $12-13 \times 2-15$ & $4-7 \times 4-7$ & $5-6 \times 7-8$ \\
\hline Seed surface & Smooth & Rugose & Slightly rugose \\
\hline $\begin{array}{l}\text { Plant stature (max. } \\
\text { height, } m \text { ) }\end{array}$ & 6 & 25 & 3 \\
\hline Habitat & Dry forest & Moist forest & Dry forest \\
\hline Distribution & Restricted to Chiapas & $\begin{array}{l}\text { Widespread (Mexico to } \\
\text { Panama) }\end{array}$ & Northern Venezuela \\
\hline
\end{tabular}

Croton and the sister clade of sect. Cyclostigma (van Ee et al. 2011). It is also one of the few sections of Croton with a distinct synapomorphy, i.e., the presence of three inflated lobes at the apex of the fruit columella (Riina et al. 2009; van Ee et al. 2011). So, C. xalapensis can be easily distinguished from C. calcareus sp. nov. by its shrubby habit and its trilobed columella apex. Croton verapazensis, from Central America, is superficially similar to C. calcareus sp. nov. and it also grows in dry forest. However, it is member of a different clade of Neotropical Croton, namely C. sect. Corylocroton G.L.Webster, and can be distinguished from any member of sect. Cyclostigma, including C. calcareus sp. nov., mainly by its unique petiolar nectary gland morphology (apical part with almost the same diamater as the stipe; in sect. Cyclostigma it is much wider than the stipe), presence of stellate-lepidote trichomes, leaf margins serrate to coarsely dentate and presence of unisexual cymules at the base of the inflorescence axis. Finally, as in C. draco, both C. xalapensis and C. verapazensis also have much longer mature inflorescences and smaller capsules and seeds than C. calcareus sp. nov.

\section{Acknowledgements}

We thank the staff of herbarium MA for their support as well as David S. Gernandt and Ubaldo Melo Samper Palacios from MEXU for providing information and images of specimens. We are grateful to Montserrat Martínez Ortega (Universidad de Salamanca), Alberto Herrero (RJB-CSIC) and Mercedes 
Sanjuan (RJB-CSIC) for helping LMR to pursue a summer internship at the RJB-CSIC under the supervision of RR. We appreciate helpful comments from the editor and two anonymous reviewers.

\section{References}

Arévalo R., van Ee B.W., Riina R., Berry P.E. \& Wiedenhoeft A.C. 2017. Force of habit: shrubs, trees and contingent evolution of wood anatomical diversity using Croton (Euphorbiaceae) as a model system. Annals of botany 119: 563-579. https://doi.org/10.1093/aob/mcw243

Areces-Berazain F. \& Vega-Lopez V.J. 2019. Hampea lanceolata (Malvaceae, Malvoideae), a new species from Chiapas and Oaxaca, Mexico. Phytotaxa 404: 121-126. https://doi.org/10.11646/phytotaxa.404.3.4

Bachman S., Moat J., Hill A.W., de Torre J. \& Scott B. 2011. Supporting red list threat assessments with GeoCAT: Geospatial conservation assessment tool. ZooKeys 150: 117-126.

https://doi.org/10.3897/zookeys.150.2109

Darriba D., Taboada G.L., Doallo R. \& Posada D. 2012. jModelTest 2: more models, new heuristics and parallel computing. Nature Methods 9: 772. https://doi.org/10.1038/nmeth.2109

Farias S.Q., Medeiros D. \& Riina R. 2019. A new species of dragon's blood Croton (Euphorbiaceae) endemic to the Serra dos Órgãos (Rio de Janeiro, Brazil). PhytoKeys 126: 13-24.

https://doi.org/10.3897/phytokeys.126.35649

Feio A.C., Meira R.M. \& Riina R. 2018a. Leaf anatomical features and their implications for the systematics of dragon's blood, Croton section Cyclostigma (Euphorbiaceae). Botanical Journal of the Linnean Society 187: 614-632. https://doi.org/10.1093/botlinnean/boy038

Feio A.C., Ore-Rengifo M.I., Berry P.E. \& Riina R. 2018b. Four new species of dragon's blood Croton (Euphorbiaceae) from South America. Systematic Botany 43: 212-220.

https://doi.org/10.1600/036364418X697111

Feio A.C., Riina R. \& Meira R.M.S.A. 2016. Secretory structures in leaves and flowers of two dragon's blood Croton (Euphorbiaceae): New evidence and interpretations. International Journal of Plant Sciences 177: 511-522. https://doi.org/10.1086/685705

Hijmans R.J., Phillips S., Leathwick J. \& Elith J. 2013. dismo: Species Distribution Modeling. R package version 0.8-17. Available from https://cran.r-project.org/web/packages/dismo/ [accessed 21 Apr. 2020].

Hirai R.Y., Sundue M.A. \& Prado J. 2014. Adiantum alan-smithii (Pteridaceae), a new maidenhair fern from Chiapas, Mexico. Systematic Botany 39: 380-383. https://doi.org/10.1600/036364414X680942

IUCN. 2012. IUCN Red List Categories and Criteria, version 3.1., Second Ed. IUCN, Gland/Cambridge. Available from https://portals.iucn.org/library/node/10315 [accessed 26 Jul. 2019].

Jones K. 2003. Review of Sangre de Drago (Croton lechleri) - A South American tree sap in the treatment of diarrhea, inflammation, insect bites, viral infections, and wounds: traditional uses to clinical research. Journal of Alternative and Complementary Medicine 9: 877-896.

https://doi.org/10.1089/107555303771952235

Maddison W.P. \& Maddison D.R. 2017. Mesquite: a modular system for evolutionary analysis. Version 3.2. Available from http://mesquiteproject.org [accessed 26 Jul. 2019].

Martínez-Meléndez N., Martínez-Camilo R., Pérez-Farrera M.Á., Skog L.E. \& Barrie F. 2014. Una especie nueva de Alsobia (Gesneriaceae) de Chiapas, México. Revista mexicana de Biodiversidad 85: 343-348. https://doi.org/10.7550/rmb.32633 
Ochoa-Gaona S. 1996. La vegetación de la Reserva El Ocote a lo largo del cañón del río La Venta. In: Vásquez M.A. \& March I. (eds) Conservación y Desarrollo sustentable en la Selva El Ocote, Chiapas: 45-86. El Colegio de la Frontera Sur, San Cristóbal de las Casas.

Ortiz-Díaz J.J., Arnelas I. \& Pinzon J.P. 2016. Coccoloba tunii (Polygonaceae), a new species from Chiapas (Mexico). Phytotaxa 275: 75-80. https://doi.org/10.11646/phytotaxa.275.1.9

Rambaut A. 2006. FigTree v1.3.1. Available from http://tree.bio.ed.ac.uk/software/figtree [accessed 22 Jul. 2019].

Rambaut A., Suchard M.A, Xie D. \& Drummond A.J. 2014. Tracer v1.7.1.

Available from http://beast.bio.ed.ac.uk/Tracer [accessed: 24 July 2019].

Riina R., Berry P.E. \& Cornejo X. 2007. A new species of "sangre de drago" (Croton section Cyclostigma, Euphorbiaceae) from coastal Ecuador. Brittonia 59: 97-101.

https://doi.org/10.1663/0007-196X(2007)59[97:ANSOSD]2.0.CO;2

Riina R., Berry P.E. \& van Ee B.W. 2009. Molecular phylogenetics of the dragon's blood Croton section Cyclostigma (Euphorbiaceae): A polyphyletic assemblage unraveled. Systematic Botany 34: 360-374. https://doi.org/10.1600/036364409788606415

Riina R., Berry P.E., Secco R.D.S., Meier W. \& Caruzo M.B.R. 2018. Reassessment of Croton sect. Cleodora (Euphorbiaceae) points to the Amazon Basin as its Main Center of Diversity. Annals of the Missouri Botanical Garden 103: 330-350. https://doi.org/10.3417/2018131

Ronquist F., Teslenko M., van der Mark P., Ayres D., Darling A., Höhna S., Larget B., Liu L., Suchard M.A. \& Huelsenbeck J.P. 2012. MrBayes 3.2: Efficient Bayesian phylogenetic inference and model choice across a large model space. Systematic Biology 61: 539-542. https://doi.org/10.1093/sysbio/sys029

Ruiz-Sanchez E. 2015. Parametric and non-parametric species delimitation methods result in the recognition of two new Neotropical woody bamboo species. Molecular Phylogenetics and Evolution 93: 261-273. https://doi.org/10.1016/j.ympev.2015.08.004

Salatino A., Salatino M.L.F. \& Negri G. 2007. Traditional uses, chemistry and pharmacology of Croton species (Euphorbiaceae). Journal of the Brazilian Chemical Society 18: 11-33.

https://doi.org/10.1590/S0103-50532007000100002

Santos R.F., Riina R. \& Caruzo M.B.R. 2017. Diversity of arborescent lineages of Crotoneae (Euphorbiaceae) in the Brazilian Atlantic Rain Forest. Plant Systematics and Evolution 303: 1467-1497. https://doi.org/10.1007/s00606-017-1441-8

Steinmann V.W. \& Carrillo-Reyes P. 2018. A revision of the New World Euphorbia adiantoides complex (Euphorbiaceae). Phytotaxa 350: 201-222. https://doi.org/10.11646/phytotaxa.350.3.1

Thiers B. continuously updated. Index Herbariorum: A Global Directory of Public Herbaria and Associated Staff. New York Botanical Garden's Virtual Herbarium.

Available from http://sweetgum.nybg.org/science/ih/ [accessed 3 Apr. 2020].

UNESCO. 2012. Selva El Ocote - United Nations Educational, Scientific and Cultural Organization. Available from

http://www.unesco.org/new/en/natural-sciences/environment/ecological-sciences/biosphere-reserves/ latin-america-and-the-caribbean/mexico/selva-el-ocote/ [accessed 26 Jul. 2019].

van Ee B.W., Riina R. \& Berry P.E. 2011. A revised infrageneric classification and molecular phylogeny of New World Croton (Euphorbiaceae). Taxon 60: 791-823. https://doi.org/10.1002/tax.603013 
Vitarelli N.C., Riina R., Caruzo M.B.R., Cordeiro I., Fuertes-Aguilar J. \& Meira R.M.S.A. 2015. Foliar secretory structures in Crotoneae (Euphorbiaceae): Diversity, anatomy, and evolutionary significance. American Journal of Botany 12: 833-847. https://doi.org/10.3732/ajb.1500017

Webster G.L., Del-Arco-Aguilar M.J. \& Smith B.A.1996. Systematic distribution of foliar trichome types in Croton (Euphorbiaceae). Botanical Journal of the Linnean Society 121: 41-57. https://doi.org/10.1111/j.1095-8339.1996.tb00744.x

Wiedenhoeft A.C., Riina R. \& Berry P.E. 2009. "Ray-Intrusive" laticifers in species of Croton section Cyclostigma (Euphorbiaceae). IAWA journal 30: 135-148. https://doi.org/10.1163/22941932-90000209

Manuscript received: 13 January 2020

Manuscript accepted: 6 March 2020

Published on: 2 June 2020

Topic editor: Frederik Leliaert

Desk editor: Radka Rosenbaumová

Printed versions of all papers are also deposited in the libraries of the institutes that are members of the EJT consortium: Muséum national d'histoire naturelle, Paris, France; Meise Botanic Garden, Belgium; Royal Museum for Central Africa, Tervuren, Belgium; Royal Belgian Institute of Natural Sciences, Brussels, Belgium; Natural History Museum of Denmark, Copenhagen, Denmark; Naturalis Biodiversity Center, Leiden, the Netherlands; Museo Nacional de Ciencias Naturales-CSIC, Madrid, Spain; Real Jardín Botánico de Madrid CSIC, Spain; Zoological Research Museum Alexander Koenig, Bonn, Germany; National Museum, Prague, Czech Republic. 


\section{Supplementary material}

Supplementary file 1

ITS alignment (fasta file) used in phylogenetic analysis including the newly generated sequences of Croton calcareus Riina \& Mateo-Ram. sp. nov. 